InVisible Culture • Issue 31: Black Studies Now and the CounterCurrents of Hazel Carby

\title{
Archival-Futurism: \\ Archives as Social Justice
}

\author{
Miranda Mims ${ }^{1}$ \\ ${ }^{1}$ University of Rochester
}

Published on: Nov 15, 2020

DOI: 10.47761/494a02f6.6d0aae11

License: Creative Commons Attribution 4.0 International License (CC-BY 4.0). 


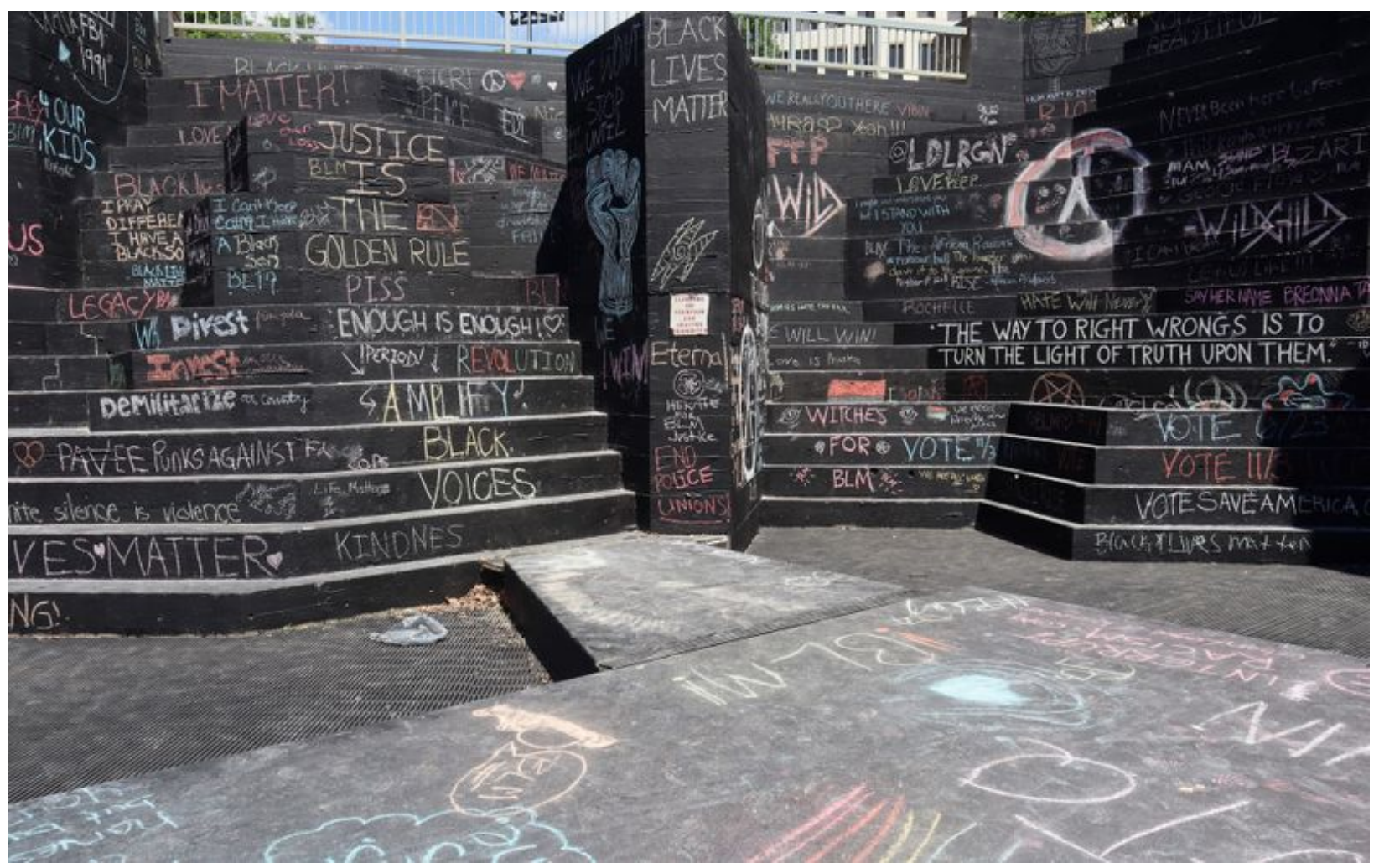

Featured image: Inscriptions at MLK Park community installation “The Empire Strikes Black," created by public artist Shawn Dunwoody. Photo by Quajay Donnell.

There should be a space for alternative realities, alternative ways of knowing, in the archive. There should be room for imagining a world in which justice not injustice triumphed.

-Hazel V. Carby, “The National Archives” $\underline{1}$

As an archivist, reading Hazel Carby's "The National Archives" is a reminder to me of the precedent on which archives were built, and the continual work we in the profession have towards transforming archival practices to reflect a social justice framework. Archives are spaces of truth and understanding as much as they are about secrecy and erasure. That which has been documented and preserved within a repository is so often duplicitous. Although archival practices have evolved, becoming more inclusive, the history of privileging the elite or powerful is still deeply entrenched in societal forms of racial and economic inequity and cultural hegemony. Archives are typically a reflection of the society in which they exist. Careful and consistent recordkeeping by ruling or governing bodies has been used as a powerful tool to strengthen 
hierarchy. $\underline{2}$ The colonial records housed in the National Archives of the United Kingdom represent one of many examples. Building archival spaces for social justice means disrupting patterns that document and preserve dominant points of view by silencing the lived experiences of everyone else; and subsequently, ensure and deepen societal amnesia.

Unfortunately, Hazel Carby's experience at the National Archive is not unusual. Archivists, curators, and practitioners are becoming more reflective of the social cost of appraisal, order, and hierarchy; however, if actions are not intentional and held to account, little will be done to change how archives actively document our complex histories. The material Carby confronts is challenging on many levels. The financial ledgers detailing profits and losses of Her Majesty's Treasury, for instance, do not speak of individuals but of property, which has insidious ramifications. Archivists at times, knowingly or unknowingly, follow the trajectory of this reality in the manner in which things have been cataloged or described in finding aids, despite the dehumanization it causes. The preservation and reproduction of dehumanization will continue to be present in archives and scholarship if they are haunted by perpetual elitism. $\underline{3}$ "Power will always expect to determine context. And the call of Justice is to trouble this expectation." $\underline{4}$ Justice in the archive can be as simple as recognizing worth or value.

Archives, both in the physical and abstract, determine how we connect to the past. $\underline{5}$ Archivists should be aware of problematic narratives in their holdings and proactive in representing alternatives to the "official" records. Archival-futurism-a term born out of my understanding of the tenets of Afrofuturism, which imagines a world centered on the lives, history, and culture of African and African diasporic people-imagines a future where those who have been traditionally silenced by archives, will be visible, not merely to exist with little or no agency, but to be the makers and shapers of the archives. $\underline{6}$ This is why it is crucial to envision alternative ways of archiving and why archival literacy is so critical. Greater awareness and advocacy ensures that those who wish to be are part of the historical record. Subsequently, archives might come to reflect the diversity and complexity of black life so often erased from them. As Marisa J. Fuentes states, black life is no less historically significant because of those erasures. $\underline{7}$ Similarly to Carby digging in the archives for her John, my family has been looking for ours. My great-grandfather, John Mims, disappeared sometime around 1912 in Byhalia, Marshall County, Mississippi. Although I learned John's story years ago, it had been 
some time since I gave it much thought. During the summer of 2019, my partner and I took a road trip through the south, spending time in Alabama, Mississippi, Louisiana, and Tennessee. In each state, we visited archives housed in historically black universities and colleges, civil rights museums, and sites of trauma. One of our stops was at the Equal Justice Initiative's National Memorial for Peace and Justice in Montgomery (EJI), where we searched the monuments for familiar names in the counties where our families lived. I was both relieved and at a loss when I did not see the name Mims. The EJI spent years researching cases like my great grandfather's, men, women and children who went missing without a trace. They documented over 4,400 persons of African descent who were burned alive, hanged, shot, tortured, and beaten to death by white mobs between the years of 1877 and 1950. 8 In many cases, the victims of racial terrorism in the US and their families never saw justice and never had their stories archived until this stone memorial was erected. Too often, there are no official records detailing the nature of these individual's deaths and disappearances unless there is a direct correlation to a supposed white "injustice." $\underline{9}$ Sometimes, the only evidence of their existence at all is their descendants.

Byhalia was the last stop on our trip. There are multiple versions of how John disappeared. The archives in Marshall County, where various family members have visited on occasion, including my first research trip in 1996, offer no answers. This is itself a version of John's disappearance. Another version is the one my family tells. According to the memory of my grandfather, who was a child at the time, unknown white men came through the front door one night and chased his father out the back. And that was the last account of John Mims. Not long after his widow, Cornelia Powers, and her two children walked from Byhalia to Memphis. We may never know what truths were lost through migration. However, what is known is that the vital records documenting John's life and death are missing. No police report was filed or retained. And an announcement of a missing person has never surfaced in any of the local or national papers. Without as much as a picture, he is a shadow. As Carby writes in "The National Archive," "As a daughter and granddaughter I was left bereft, dissatisfied and unsettled that the lives in and by the archives and by enslavement are irretrievable." 10 Acknowledging the work of archives as political-and that this work has never been neutral-is an act of social justice. Archives have the power to impose a narrative of the past, which is why some in the field have been reevaluating persistent exclusionary practices. As we begin to confront absences in the records by dismantling traditional methods of collecting, preserving, and accessing archives we need to think beyond 
merely filling the gaps in our holdings. Many historians in the 1970s sought to shift perspective by conducting history from the "bottom up." 11 Archivists can also take this approach by expanding outside the institutions that generate records, as a means of identifying, recovering, and leveraging individual and marginalized voices. In the case with Carby, confronting colonial records in government archives, there is only one reality, and nothing to balance it; thus the need to counter the historical narrative that was built on dominance and control. However, many repositories have found resistance to this effort. Larger systemic issues (e.g. racism, sexism, economic disparities, and etc.) that have governed and shaped traditional archiving persist and often overshadow what is seeking to be addressed on a local level. By utilizing emerging technologies and facilitating documentation through democratic platforms, archivists have greater access to counter-narrative content, such as online media, events, and conversation, although there are limits to this and ethical concerns, which need further investigation. $\underline{12}$

In 2017, I co-founded the Nomadic Archivists Project (NAP), an initiative to address the archival needs of the global Black world as well as the politics of archival equity. $\underline{13}$ NAP grew out of the desire for greater mobility for archivists and content creators to have honest and ungoverned conversations around legacy, memory, and access. What surfaced was that the archival gap was not an absence of material culture in a repository; the gap surfaced issues of dignity, connection, and trust. From the onset, NAP envisioned a space where curation and archiving would not simply reflect the agenda or mission of traditional repositories. We started by acknowledging that the path to archiving one's creative endeavors, political advocacy, and history is different depending on how individuals and communities understand archives and their cultural relevance. We believe that those value systems should be respected and honored.

Forging spaces centered on social justice also means being honest about limitations. Archivists and non-archivists have disparate understandings of what archives are and what they do. Historians may think every document could be worthy of study, a viewpoint premised on the belief that historiography must be informed by

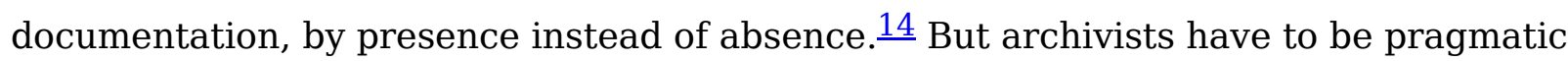
and judicial and understand that selection is inescapable; it is impossible to collect everything. The reality is that only a small percentage of material culture produced can be saved in a traditional archive. $\underline{15}$ Archivists have to weigh the value of the material for research purposes, but also the cost of custodianship. This is precisely why we must embrace alternative custodial models. 
Alternative or non-traditional modes of archiving accept that not all cultural heritage has to be removed from where it was created to be preserved or accessed. By breaking away from thinking that the "archive" has to be in a traditional repository, we can truly expand our work beyond our walls. Re-envisioning a future of equitable archival practices should include that traditional archives adopt various approaches to collection development. It includes letting go of the need to collect for prestige and to document the powerful or the majority culture, and moving toward alternative custodial models when appropriate, especially as more people take responsibility for shaping their narrative and representation. What is found in the archives is not the only way to understand the past.

As archivists, we are not passive. $\underline{16}$ We are active agents in both preserving history and collaborators in the documentation of history. $\frac{17}{}$ Our impact on the archival process is profound. We make decisions around defining, identifying, and selecting what histories should be preserved. We make choices concerning the accessioning and deaccessioning process. We design the way that a collection is physically and intellectually represented to those who pass through it. In doing so, traces of us have become part of the archive. Archival work is a heavy responsibility, and the weight of that work has consequences, as Carby found when wading through the colonial records housed in the UK's National Archives. As we continue to work towards building informed, intentional, and equitable spaces, we will move closer to an archival future that is more responsible to its constituency.

\section{Footnotes}

1. Hazel V. Carby, "The National Archives," InVisible Culture 31 (2020), http://ivc.lib.rochester.edu/the-national-archives/. $\leftrightarrows$

2. Randall C. Jimerson, Archives Power: Memory, Accountability, and Social Justice (Chicago: Society of American Archivists, 2010). $\triangleq$

3. Hazel V. Carby, "The National Archives”; Christina Elizabeth Sharpe, In the Wake: On Blackness and Being (Durham: Duke University Press, 2016).

4. Verne Harris, "Ethics and the Archives: 'An Incessant Movement of Recontextualism,'” in Controlling the Past: Documenting Society and Institutions: Essays in Honor of Helen Willa Samuels, ed. Terry Cook (Chicago: Society of American Archivists, 2011), 351. $\bullet$ 
5. Zeb Tortorici, Sins Against Nature: Sex and Archives in Colonial New Spain (Durham: Duke University Press, 2018). $\leftrightarrows$

6.

Archival-futurism is a term born out of my understanding of the tenets of Afrofuturism. In principle, Afrofuturism imagines a world centered on the lives, history, and culture of African and African diasporic people. If archives are the mirror of society, then they, too, will reflect the diversity and complexity of black life. However, Archival-futurism extends to all realities that have been erased in archives, yet, as Marisa J. Fuentes states, are no less historically significant.

See Marisa J. Fuentes, Dispossessed Lives: Enslaved Women, Violence, and the Archive (Philadelphia: University of Pennsylvania Press, 2016), 44-45, 51, 127. 7. Fuentes, Dispossessed Lives, 7, 47, 128. $\leftrightarrows$

8. “The National Memorial for Peace and Justice," Legacy Museum and National Memorial for Peace and Justice, accessed August 14, 2019, https://museumandmemorial.eji.org/memorial. $\triangleq$

9. Debra Walker King, African Americans and the Culture of Pain (Charlottesville: University of Virginia Press, 2008).

10. Carby, "The National Archives."

11. Francis X. Blouin, "The Evolution of Archival Practice and the History-Archival Divide," in Controlling the Past: Documenting Society and Institutions: Essays in Honor of Helen Willa Samuels, ed. Terry Cook (Chicago: Society of American Archivists, 2011), 322.

12. Bergis Jules, "Some Thoughts on Ethics and DocNow." DocNow, accessed August 17, 2019. https://news.docnow.io/some-thoughts-on-ethics-and-docnowd19cfec427f2.

13. Nomadic Archivist Project, https://www.nomadicarchivistsproject.com/. 14. James Oliver Horton and Lois E. Horton, eds., Slavery and Public History: The Tough Stuff of American Memory (Chapel Hill: University of North Carolina Press, 2009). 
15. Elena S. Danielson, The Ethical Archivist (Chicago: Society of American Archivists, 2010), 55.

16. Harris, "Ethics and the Archives," 345.

17. Ann Laura Stoler, Along the Archival Grain: Epistemic Anxieties and Colonial Common Sense (New Jersey: Princeton University Press, 2009). $\_$ 